\title{
日立港内における長周期波の現地観測 一河川遡上波の発生原因として一
}

Field Observation of Long-period Waves in Hitachi Port as a Cause of Wave Run-up in River Channel

\author{
神田康嗣 ${ }^{1}$ 宇多高明 ${ }^{2}$ ・平石哲也 ${ }^{3}$ ・伊藤敦史 ${ }^{4}$ ・渡邊 徹 $^{4} \cdot$ 高野泰隆 $^{5}$
}

Yasutsugu KANDA, Takaaki UDA, Tetsuya HIRAISHI, Atsushi ITO, Toru WATANABE and Tairyu TAKANO

In the Segami River flowing into Hitachi Port facing the Pacific Ocean, swell waves with solitons in front often propagate from the river mouth, causing the inundation damages. These damages are closely related to the wave run-up of the long-period waves. Field observation of these long-period waves was carried out to investigate the mechanism of the propagation of long-period waves. Waves with an extraordinary long period of $1,200 \mathrm{~s}$, which was generated as seiche on continental shelf, were observed as well as the long period waves with the period of $100 \mathrm{~s}$.

\section{1.はじめに}

茨城県管理の二級河川瀬上川は, 流域面積 $1.59 \mathrm{~km}^{2}$, 計 画高水流量 $31 \mathrm{~m}^{3} / \mathrm{s}$ (日立市渚橋の地点)で, 指定区間の流 路延長は750m である．瀬上川は，日立市の旧久慈浜駅周 辺の人家密集地域を流れ日立港（図-1, 図-2）へ流入し ている. 旧駅周辺では河道幅が狭く地盤高も低いため，こ れまでたびたび洪水被害を受けてきた。対策として河道拡 幅と掘削が行われたが，その後「う利り」の遡上現象がみ られるようになり（写真-1），上流部で時として河川水

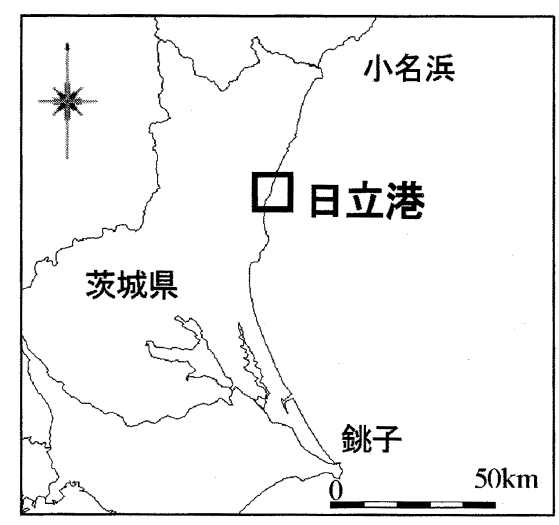

図-1 日立港内の位置

\begin{tabular}{|c|c|c|}
\hline \multicolumn{2}{|l|}{1 正会員 } & 株式会社水圏科学コンサルタント \\
\hline 2 正会員 & 工博 & 財団法人土木研究センター理事 \\
\hline 3 正会員 & 工博 & $\begin{array}{l}\text { 独立行政法人港湾技術研究所 海洋 } \text { - } \\
\text { 水工部長 }\end{array}$ \\
\hline 4 正 & & 茨城県土木部河川課 \\
\hline & 博(工) & $\begin{array}{l}\text { 株式会社水圏科学コンサルタント } \\
\text { 表取締役 }\end{array}$ \\
\hline
\end{tabular}

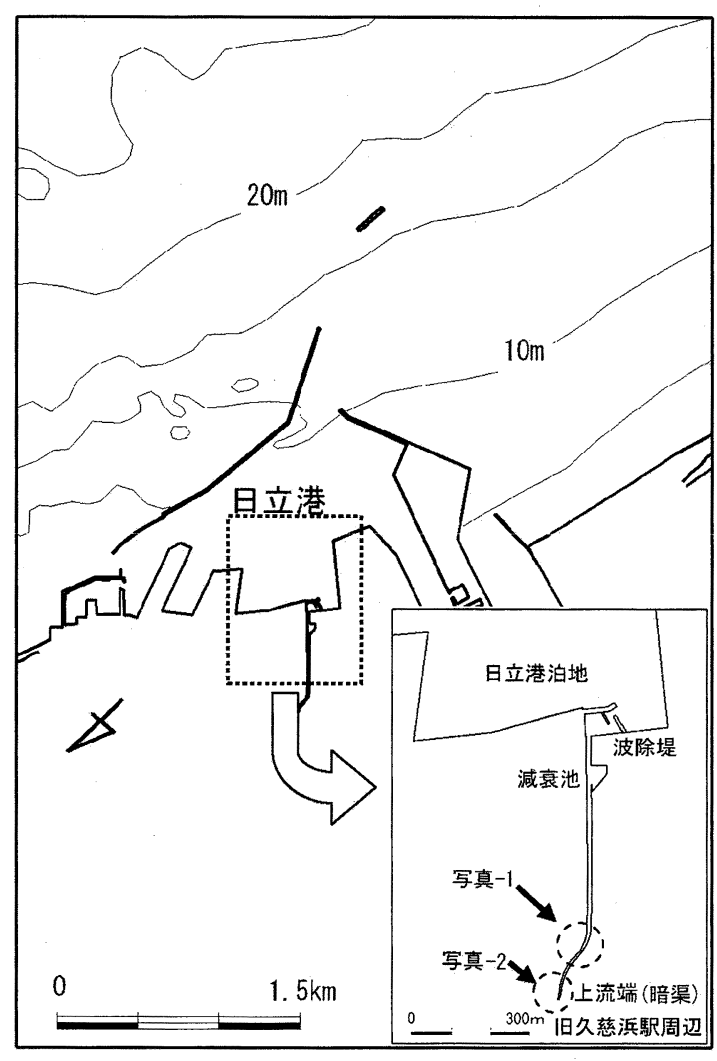

図-2 日立港および港内に流入する瀬上川の位置

が市街地に溢れる被害が発生している（写真-2）。この現 象は日立港内の長周期波が河口部で増幅し，河道内で段 波となって遡上することが原因である可能性が高い，これ まで瀬上川では，河道内での対策として，河口部での流入 


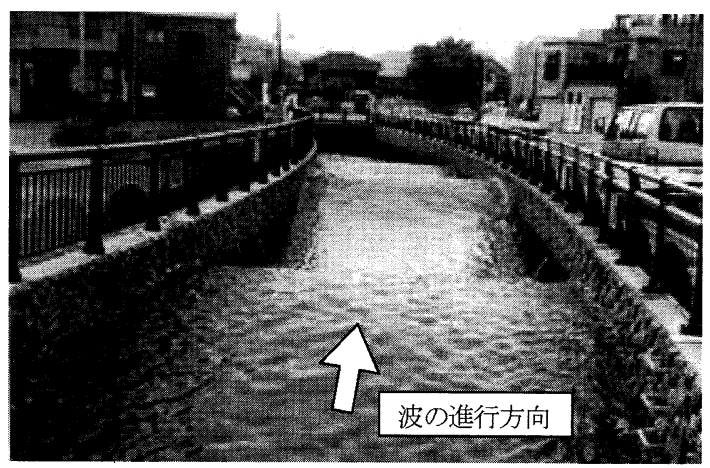

写真-1 瀬上川に遡上する長周期波(先端部でソリトン分裂 が出現しているようにみえる)

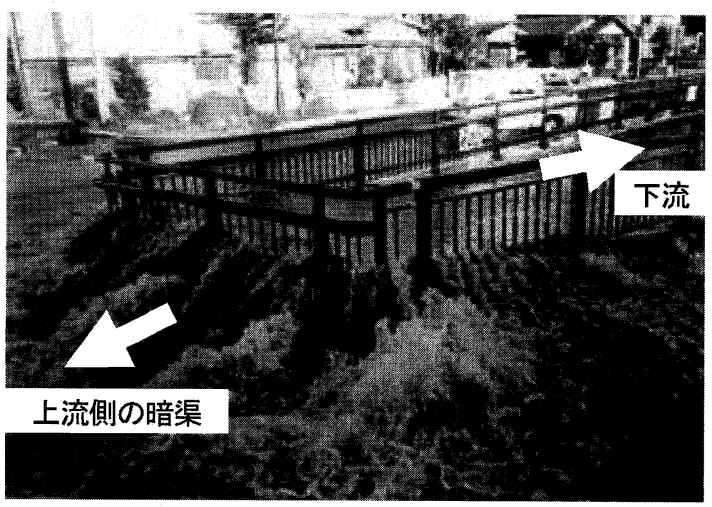

写真-2 暗渠前面での溢水状況 (2002年10月22日撮影)

を抑制する波除堤，河道での共振周期をずらすための減衰 池などを建設することにより頻繁に発生していた溢水被害 を減ずる手法が試されてきた。しかしながら，周辺住民の 安全を確保するには，護岸の嵩上げなどの追加対策が望ま れていることから，所要高さの計画に先立って発生原因を 含めた定量的な調查が必要となった。本研究では, それら の調查結果をむとに，遡上要因となる港内の長周期波の実 態を把握し，河道内対策のみならず港内における対策す踏 まえた総合的な対策検討に資することを目的とした。

\section{2. 現地観測の概要}

現地観測は，日立港港内 3 地点（図-3 $の \mathrm{~W}-1 \sim \mathrm{W}-3$ ), 瀬上川河口（W-4）及び河道内（W-5, W-6） 3 地点の計 6 地点に自記式水圧計を設置し，0.1秒間隔で約 3 ヶ月間（2 007年 8 月 23 日 11月22日）の連続観測を行った。長周期 波の統計処理は, 100 200秒程度の周期を対象とする場 合, 連続デー夕を 3 時間毎に区切って解析した. また, 長 期間の連続デー夕が得られたことから，さらに長周期の振 動について解析する目的で，12時間毎に区切ったデー夕も 使用した。

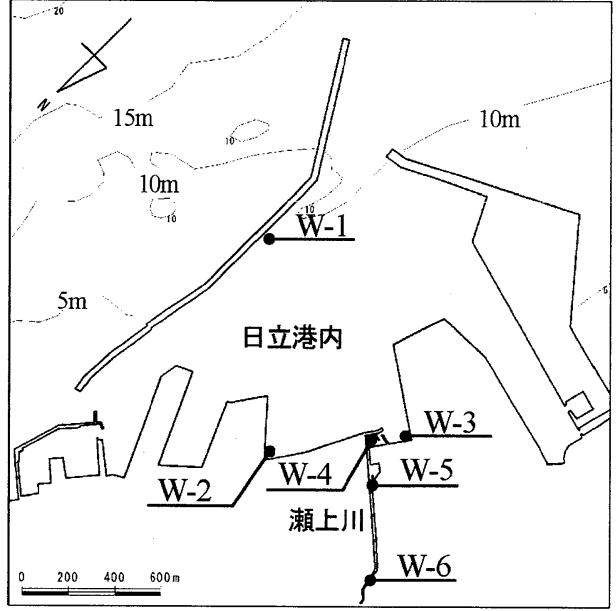

図-3 波高観測地点

観測中には 9 号から 20 号までの 12 個の台風が発生したが, そのうち最む顕著な長周期波を観測したのは, 台風 9 号で あり，9月 1 日頃加ら南東海上に接近し，ゆっくりと北上 した。 その後 9 月 6 日に関東に接近したため，日立港前面 では 9 月 7 日未明に通常波浪の最大波高 $4 \mathrm{~m}$, 港内の W-3 での長周期波高 $70 \mathrm{~cm}$ を記録した．以下の検討では，主に この時の30秒以上の周期成分から計算できる長周期波高の ピーク時のデータを中心に解析を進めた。

\section{3. 長周期波の実態}

\section{(1) 擾乱時に卓越する100秒台の長周期波}

日立港内に観測された長周期波について，同一時期に観 測された隣接する常陸那珂港港外の波浪デー夕を日立港前 面に変換したデー夕と比較した(波浪の浅海変形計算に

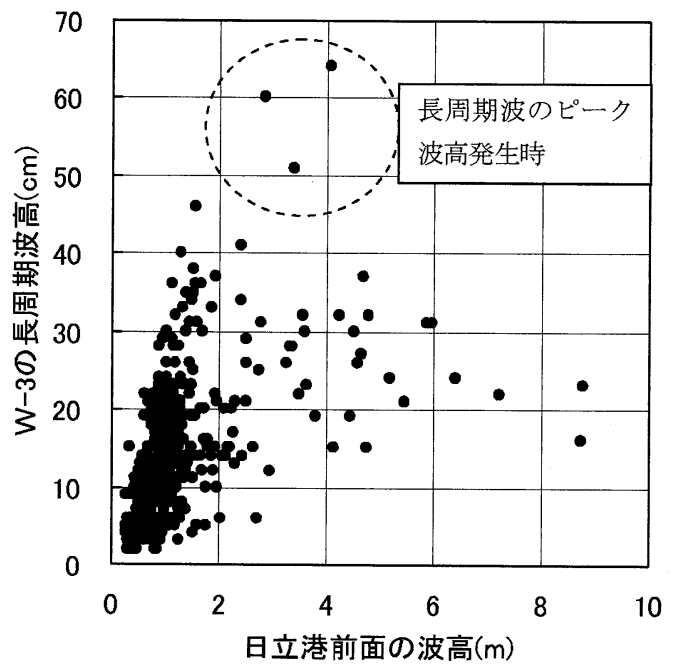

図-4 通常波浪の波高と港内の長周期高との関係 
よって波高・周期・波向のランク毎の変換係数を作成する 方法によって変換). その結果, 通常周期の波高との相関 はあまり高くないものの（図-4），南寄りの波向の通常波 浪が長く襲来した場合に長周期波が発達する傾向にあるこ とが判明した。低気圧や台風が，沿岸部を北上して急激に 発達する擾乱時ではなく, 南東沖にあってゆっくりと移動 し，うねり性の波浪が到達する状況がそれにあたる。港内 で発達する長周期波の平均周期は $100 \sim 150$ 秒程度であり, これが進行波で日立港港口付近（水深 $10 \mathrm{~m}$ 程度）に来襲 したとすると，波長は $1500 \mathrm{~m}$ 程度となる，日立港の東防波 堤は北東方向に約 $3000 \mathrm{~m}$ の延長があり, この程度の長周 期波が北寄りから入射した場合，遮蔽効果があるあのと考 えられる. 港内の長周期波のピークが南寄りの波向時に発 達しているのは，防波堤の位置による影響が大きい(図-5).



図-5 通常波浪の波向と港内の長周期高との関係

この 100 秒台の長周期波は，W-2 および W-3 の位置する 岸壁で囲まれたコの字型の泊地内に抄ける共振モードと概 ね一致している。例えば $T=2 L / \sqrt{g h}$ で固有振動周期を 概算すると, 水路長 $\mathrm{L}=600 \mathrm{~m}$, 水深 $\mathrm{h}=8 \mathrm{~m}$, 重力加速度 $\mathrm{g}=9.8 \mathrm{~m} / \mathrm{s}^{2}$ として周期 $\mathrm{T}=136$ 秒であり, 観測された 100 秒 台之同程度の 1 次モードの振動周期が得られる. また, W-2 および W-3 の実測值の波形を重ねても， $180^{\circ}$ の位相差が 顕著に認められ，W-2 と W-3 を腹とした 1 次モードで振 動している様子が確認できる（図-6).

日立港内には種々の長周期波が存在するが，100秒台の 長周期波が W-2 および W-3 間で振動・増幅する過程で, 河口部（波除堤に囲まれた泊地状の部分：W-4 の位置） に進入し，それがさらに上流部へと伝達するのが長周期波 の河川に遡上するメカニズムであると考える.

\section{(2) 気象要因による長周期波}

本観測で発生した長周期波高の最大值は, 波高 $70 \mathrm{~cm}$ 周



図-6 W-2 とW-3 の長周期波の水位変動

期130秒であり，このときの日立港前面の通常波浪は波高 $4 \mathrm{~m}$, 周期 9 秒程度であった。一般的に波浪の擾乱に伴う 長周期波が通常波の波高の $10 \%$ 程度とすれば（合田 （1990）による水深 $10 \mathrm{~m}$ 付近におけるサーフビートの振幅 比の例), 観測された長周期波は, 来襲波浪の大きさに比 べ, エネルギーレベルの高いあのが発生しているといえる. 溢水被害の発生時に最屯顕著に視認できるのがこの長周期 波の遡上であるが, 実際にはさらに以下の要因が重なって 溢水被害が増大していると推定される。

(1) 大潮の満潮で、潮位が H.W.L.付近であること

(2) 遡上の途中で段波状になるため上流端（暗渠部分で 溢れる) での最高水位が大きくなること

(3) 気象要因の長周期波が重なっていること

ここで，(1)之(2)の現象は，既存の調查（宇多ら，2002； 栗原ら, 2004 ; Takano, 2004）であ明ら功さ机ていこ とであるが, (3)の現象は陸棚波としての存在は指摘されて いるあのの (宇野木，1959など), 本観測による長期間の データから改めて確認されたあのである.

100 3000秒の長周期波を対象にエネルギースペクトル を求め, 時系列に比較したものが図-7である. 図の上段 は，常陸那珂港の観測波浪を日立港前面に変換した後の 通常波浪の波高・周期，波向であり，下段は港内の W-3 地点における通常波の波高と 100 秒台 ( $\triangle$ 印) 及び1000秒 台（の印）の長周期波のエネルギーの時間的変化を示す. これによると100秒台にピークをあつ長周期波は、通常波 浪のう衫り成分と概称同期しており，う衫りの発生に起因 するあのとみることができる．これに対して1000秒台（20 分程度）の長周期波は，ほぼコンスタントに発生しており， さらに通常波浪のピーク前にはエネルギーが 1 オーダー大 きくなって，波高にして2〜3 倍になることもわかった (図-8 のスペクトル図参照).

港内（W-3）で観測された周期1000秒台の長周期波の最 大波高は $20 \mathrm{~cm}$ 程度であるが, 河道内（W-6）では $30 \mathrm{~cm}$ 程 度と1.5倍に増幅される傾向がみられた（図-9).これは 100 $\sim 150$ 秒の長周期波の波高亡比較すると $50 \%$ 程度の大きさ となる場合があることを示しており，長周期波対策に関す 


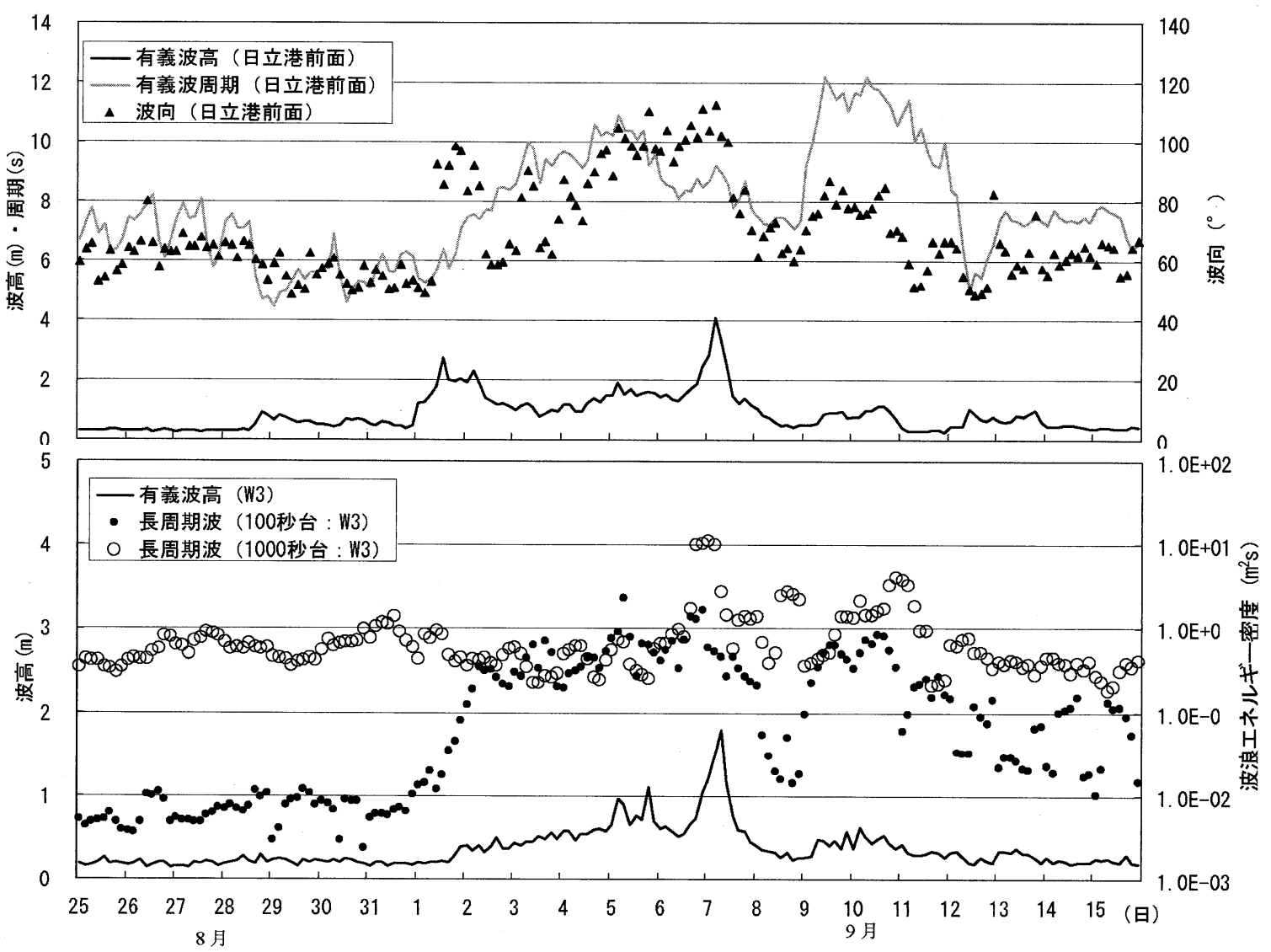

図-7 外洋波と港内(W-3)における長周期波エネルギーの経時変化

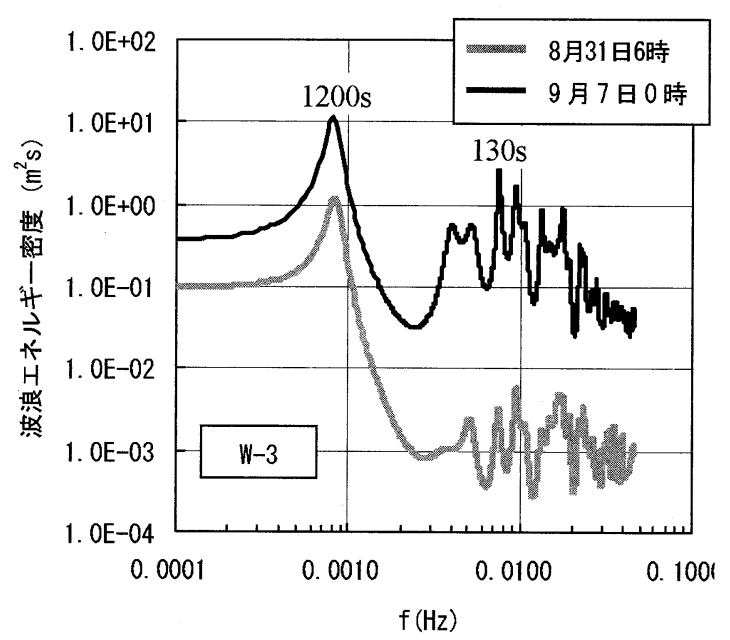

図-8 静穏時と擾乱時の長周期波のスペクトルの比較

長周期波が発生するのは, 気圧変動などの気象要因による ものが考えられ，沿岸部で反射した波がさらに岸向きに屈 折して浻岸域にトラップされる大陸棚セイシュの現象とし て理解される. 通常, 気象要因による長周期波は潮位偏差

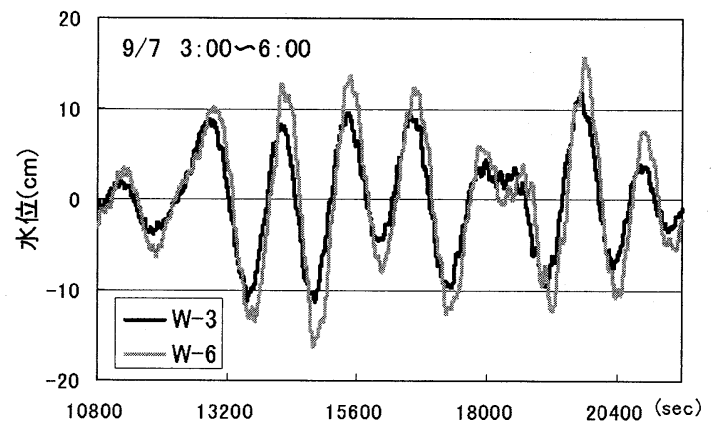

図-9100秒台の長周期波の港内と河道内の比較

に含まれるものとして扱われるが，上記のように地形的な 条件によっては増幅することがあることには注意すべきで あろう。

\section{4. 長周期波の計算}

大陸棚セイシュの影響を確認するため，線形長波方程式 による数值計算（平石ら，1988）によって，沿岸にトラッ プされる長周期波を再現した。計算条件を表-1に示す. 
入射波は規則波を沖側境界から一様に入射させており，汀 線および構造物を陸側境界として全反射させている.

計算結果を図-10 に示す．図の波高比分布をみると，銚 子半島に集中しているが, 北側の沿岸部についてあ数 $10 \mathrm{~km}$ 程度の間隔で腹と節をあつように増幅部分があり, 沿岸にトラップされている様子が伺える. 日立港付近では 4 6 倍程度の分布域が確認でき, 本観測で得られた害測 値0.2 0.3 $\mathrm{m}$ の波高から逆算すると, 沖合で数 $\mathrm{cm}$ の気象 要因に上る長周期の水面変動が発生していると推定される. 大陸棚セイシュのような長周期波は, 本研究の対象である 河川に遡上する長周期波のような变動成分ではなく, 本来 設計高潮位に含まれるあのといえる. しかし, 河口内で増 幅すること6確認されたことから，場合によっては護岸高 さの決定等に大きく影響を及ぼすことも考えられる. した がって, 今後, 変動成分としてどの程度影響するか検討す ることが望まれる.

表-1 長周期波の計算条件

\begin{tabular}{|c|c|}
\hline 項目 & 設定値 \\
\hline 入射波周期 & $1200 \mathrm{sec}$ \\
\hline 入射波波高 & $0.1 \mathrm{~m}$ \\
\hline 計算領域 & $157 \mathrm{~km} \times 176.5 \mathrm{~km}$ \\
\hline 格子間隔 & $500 \mathrm{~m}$ \\
\hline 格子数 & $314 \times 353$ \\
\hline 計算時間間隔 & $1.5 \mathrm{sec}$ \\
\hline 計算時間 & $24900 \sec ^{*}$ \\
\hline 計算ステップ数 & 16600 \\
\hline 造波数 & 20 波 \\
\hline 潮位 & $1.4 \mathrm{~m}$ \\
\hline
\end{tabular}

\section{5. 結論}

(1)日立港内の長周期波について長期間の連続観測により 実態把握を行った。これによれば日立港の港内では種々の 長周期振動が確認されたが，W-2 および W-3 の岸壁間は 100 秒台の 1 次モードの固有振動特性があり, その周期の 長周期振動が選択的に発生している. 瀬上川の河口部はこ の岸壁の一方に面しており, 増幅した振動を受け取る形に なっている.このモードの波が河川上流の W-4〜W-6 で観 測され，河川の主な溢水の原因になっていることがわかっ た.

(2)日立港内では約 1200 秒の長周期振動も確認された.

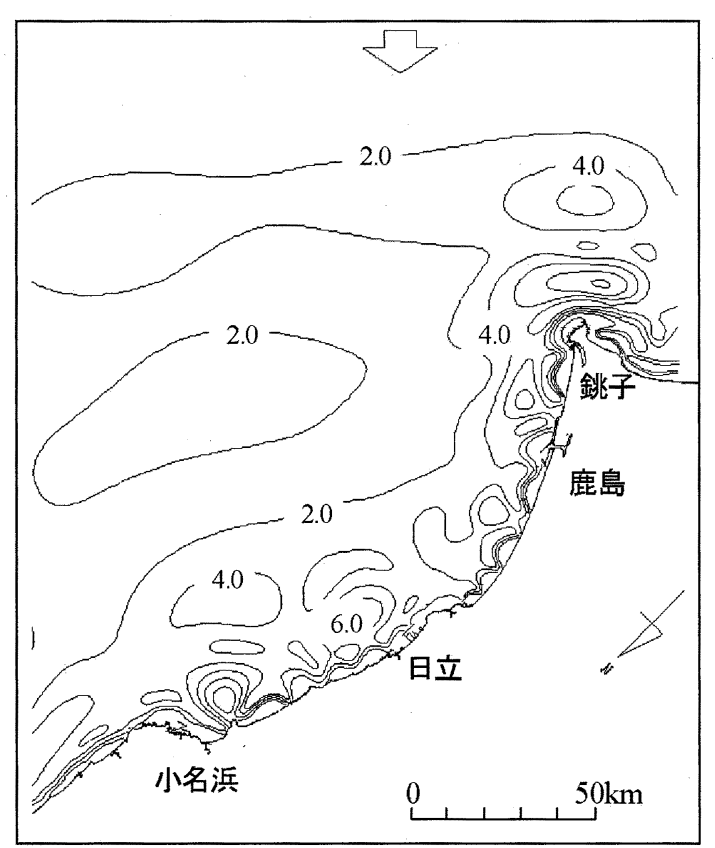

図-10 沿岸域における $\mathrm{T}=1200 \mathrm{~s}$ の長周期波の波高比分布

これは, 大陸棚セイシュの影響と考えられ，定常的に存在 しているが，気圧変動などの気像要因であるため，台風な どの擾乱とともに通常の 2 3 倍に発達することもわかっ た．日立港では，通常 $10 〜 20 \mathrm{~cm}$ の波高であるが， $30 \mathrm{~cm}$ 程度に発達することああり，場合によっては設計時の潮位 としてのみならず，長周期成分として考慮する必要がある.

\section{参 考 文 献}

Takano, T., T. Uda, Y. Ohki, Y. Kanda, M. Serizawa, H. Yamanaka and S. Sukegawa (2002):Inundation caused by swells and long-period waves penetrating from river mouth and its countermeasures - a case study at the Segami River, Ibaraki Prefecture, Japan, Jour. of Hydroscience and Hydrauric Engineering, Vol.20, No.2, pp.169-185.

宇野木早苗 (1959): 港湾のセイシュと長周期波について, 第 6 回海岸工学講演会講演集, pp.1-11.

高山知司・平石哲也（1988）: 数値計算と現地観測による港内副 振動特性の検討，港湾技研資料No.636,70p.

合田良實 (1990)：港湾構造物の耐波設計, 増補改訂版, 鹿島 出版会, 333p.

宇多高明 - 山中 博 - 助川 進 - 高野泰隆 - 大木康弘 - 神田康嗣 芹沢真澄 (2002)：河口加らの遡上波による高潮災害とその 対策一茨城県の瀬上川の例一, 水工学論文集, 第46巻, pp.349-354.

栗原一美・宇多高明・鱠谷純夫・高野泰隆 - 大木康弘・神田康 嗣 (2004): 小河川の河口を通じた長周期波遡上の現地観測一 日立市瀬上川の例一, 水工学論文集, 第48巻, pp.349-354. 